\title{
Kamil Dworaczek
}

\section{Władze Związku Sowieckiego wobec katastrofy czarnobylskiej}

Zarys treści: Artykuł opisuje działania władz sowieckich w pierwszych kilkunastu dniach po katastrofie czarnobylskiej. Poruszona została w nim kwestia likwidacji skutków awarii, ochrony ludności przed promieniowaniem oraz polityka informacyjna w kraju i za granicą. Zawiera też próbę odpowiedzi na pytanie, gdzie popełniono błędy i z czego one wynikały.

Outline of content: The article describes the actions of the Soviet authorities undertaken throughout the first fortnight after the Chernobyl disaster. It addresses the questions of the liquidation of the disaster's consequences, protection of people against radiation exposure, and information policy both in the country and abroad. It also attempts to answer the question where the mistakes were made and from what they resulted.

Słowa kluczowe: Czarnobyl, katastrofa w Czarnobylu, Komitet Centralny Komunistycznej Partii Związku Sowieckiego (KC KPZS), Michaił Gorbaczow, elektrownie atomowe

Keywords: Chernobyl, Chernobyl disaster, Central Committee of the Soviet Communist Party, Mikhail Gorbachev, nuclear power plants

Paradoksalnie wiedza historyczna o katastrofie w Czarnobylu, opierająca się na rzetelnych badaniach historycznych, jest w Polsce niewielka. Wszyscy słyszeli o katastrofie, większość nawet ją doskonale pamięta, ale znajomość tego tematu jest nader powierzchowna. Tyczy się to wszystkich aspektów związanych z konsekwencjami awarii, w szczególności jednak reakcji władz sowieckich ${ }^{1}$. Wiadomo, że Rosjanie milczeli, a wzrost radioaktywności odnotowali Szwedzi i zaalarmowali

${ }^{1} \mathrm{~W}$ artykule będę pisał o władzach sowieckich rozumianych jako władze centralne w Moskwie, pomijam tu reakcje władz republik szczególnie dotkniętych wskutek awarii: Białoruskiej SRS i Ukraińskiej SRS. 
świat. Szczególnie okres milczenia władz sowieckich między 26 a 28 kwietnia 1986 r., czyli między katastrofą a pierwszym komunikatem władz sowieckich, jest w Polsce słabo znany. Obowiązuje narracja, że „Rosjanie wszystko chcieli ukryć” i tym prostym wytrychem tłumaczy się postawę Kremla. O tym, co jednak działo się na szczytach władzy, o podejmowanych tam decyzjach i dyskusjach nic nie znajdziemy w polskiej historiografii. Niewiele lepiej przedstawiają się pod tym względem publikacje zagraniczne, które skupiają się przede wszystkim na samej elektrowni i obszarach bezpośrednio do niej przylegających, bardzo mało jest prac analizujących postawę obozu władzy w tym czasie ${ }^{2}$.

Brak publikacji na ten temat wynika również z obiegowego przekonania o niedostępności materiałów archiwalnych $\mathrm{z}$ tego okresu. Mimo iż dla dokumentów związanych z awarią w Czarnobylu okres karencyjności mija w 2026 r., to część z nich ujrzała już światło dzienne. Dotyczy to przede wszystkim fondu 89 znajdującego się w Rosyjskim Państwowym Archiwum Historii Najnowszej (RGANI Rossijskij gosudarstwiennyj archiw nowiejszej istorii) ${ }^{3}$. Jest to zbiór dokumentów Komunistycznej Partii Związku Sowieckiego (KPZS) wydzielony na początku lat dziewięćdziesiątych w związku ze sprawą toczącą się w Sądzie Konstytucyjnym Federacji Rosyjskiej o „antykonstytucyjnej działalności partii komunistycznej”. Do procesu działaczy komunistycznych ostatecznie nie doszło, ale dzięki całej sprawie ujawniono niektóre dokumenty KPZS, w tym także dotyczące Czarnobyla. Ich kopie znajdują się też w Instytucie Hoovera oraz na Uniwersytecie Harvarda, część również w Bibliotece Kongresu ${ }^{4}$. Udało mi się uzyskać kopie wszystkich dokumentów z tego zbioru, dotyczących interesującego mnie okresu ${ }^{5}$.

2 Do wyjątków należą wydane niedawno książki: S. Plokhy, Chernobyl. The History of a Nuclear Catastrophe, New York 2018; A. Higginbotham, Midnight in Chernobyl. The Untold Story of the World's Greatest Nuclear Disaster, London 2019. Obie doczekały się także już polskich przekładów: S. Plokhy, Czarnobyl. Historia nuklearnej katastrofy, tłum. M. Fedyszak, Kraków 2019; A. Higginbotham, O pótnocy w Czarnobylu, tłum. R. Filipowski, Kraków 2019 (w przypadku pracy Plokhy'ego odwołuję się do wersji anglojęzycznej, a Higginbothama - do polskiego przekładu). Zauważyć jednak trzeba, że autorzy ci nie wykorzystali wielu dostępnych dokumentów wytworzonych przez KC KPZS. Trzeba wspomnieć także o innych pracach amerykańskich historyków: N. Daniloff, Chernobyl and Its Political Fallout: A Reassessment, „Demokratizatsiya. The Journal of Post-Soviet Democratization” 12 (2004), no. 12, s. 117-132; E. Geist, Political Fallout: The Failure of Emergency Management at Chernobyl', „Slavic Review” 74 (2015), no. 1, s. 104-126. Spośród prac rosyjskojęzycznych należy przede wszystkim zwrócić uwagę na dorobek Natalii Baranowskiej, w tym m.in. monografię pt. Ispytanije Czernobylem, Kijów 2016.

3 Pismo do autora $\mathrm{z}$ Rossijskij gosudarstwiennyj archiw nowiejszej istorii (dalej: RGANI), 27 II 2019. Za pomoc i rady w kwestii zawartości rosyjskich archiwów dziękuję dr. hab. Janowi Szumskiemu.

${ }^{4}$ Pracownicy Biblioteki wydali angielskie tłumaczenie niektórych dokumentów w książce pt. Revelations from the Russian Archives. Documents in English Translation, ed. D.P. Koenker, R.D. Bachman, Washington 1997. Znajduje się w niej także kilka dokumentów dotyczących katastrofy czarnobylskiej.

${ }^{5}$ Przede wszystkim ze strony internetowej: nsarchive2.gwu.edurusPerestroikaChernobyl.html (dostęp: 18.02.2019) oraz dzięki uprzejmości pracowników Biblioteki Kongresu USA, głównie Harolda Leicha, któremu przy tej okazji chciałbym złożyć serdeczne podziękowania za pomoc. Za wsparcie przy tłumaczeniu dokumentów dziękuję Natalii Nikolskiej. 
Nie są to jednak wszystkie dokumenty, do których dotarłem. Sprawą Czarnobyla jeszcze w latach osiemdziesiątych żywo interesowała się dziennikarka z Żytomierza Ałła Jaroszynska, która w 1989 r. została wybrana do Rady Najwyższej ZSRS i jako deputowana działała w komisji badającej katastrofę czarnobylską. Udało jej się wówczas nielegalnie wynieść i skserować w redakcji „Izwiestii” m.in. 40 protokołów z posiedzenia Grupy Operacyjnej Biura Politycznego Komitetu Centralnego KPZS (BP KC KPZS) powołanej w związku z katastrofą ${ }^{6}$. Autorka omówiła je w kilku swoich publikacjach ${ }^{7}$, a ich komplet zamieściła w jednej ze swoich pierwszych książek, pt. Czernobyl. Sowierszenno Siekrietno ${ }^{8}$. Do tej pory jednak historycy w zaskakująco małym stopniu wykorzystywali te jakże cenne materiały ${ }^{9}$. Warto przypomnieć, że po katastrofie na szczeblu centralnym utworzono w sumie trzy komisje zajmujące się likwidacją jej następstw. Pierwszą i najczęściej wspominaną była Komisja Rządowa, która w początkowym okresie pracowała pod przewodnictwem wicepremiera Borysa Szczerbiny. Działała ona na miejscu i brała udział w podejmowaniu kluczowych decyzji ${ }^{10}$. Niestety nie mamy dostępu do protokołów z jej posiedzeń, więc na temat jej prac niewiele można powiedzieć. Kolejną komisją była wspomniana Grupa Operacyjna BP KC KPZS pod kierownictwem premiera Nikołaja Ryżkowa. To właśnie Grupa Operacyjna odgrywała najważniejszą rolę w procesie decyzyjnym dotyczącym Czarnobyla, jej postanowienia najczęściej akceptowali BP i sam Michaił Gorbaczow. Prześledzenie jej protokołów daje zatem dobry ogląd postawy władz sowieckich i podejmowanych przez nie decyzji. Trzecia komisja odgrywała najmniejszą rolę i jej kompetencje były najwęższe. W związku z niezadowalającą opieką medyczną nad poszkodowaną ludnością powołano do życia Komisję Rządową ds. Opieki Medycznej, kierowaną przez wiceministra zdrowia ZSRS Olega Szczepina. Do jej zadań należało wyłącznie zapewnienie właściwej opieki medycznej ofiarom awarii ${ }^{11}$.

${ }^{6}$ A. Jaroszynska, Czernobyl. Bolszaja łoż, Moskwa 2011. Korzystałem z elektronicznej wersji książki: https://www.e-reading.club/bookreader.php/1017992/Yaroshinskaya_-_Chernobyl._Bolshaya_ lozh.html (dostęp: 12.06.2019). Przytaczane informacje znajdują się w rozdz. 8 .

7 Zob. m.in.: A. Jaroszynska, Czernobyl. Bolszaja...; eadem, Chernobyl. The Forbidden Truth, Lincoln 1995.

8 Eadem, Czernobyl. Sowierszenno Siekrietno, Moskwa 1992.

9 Ze znanej mi literatury przedmiotu tylko Natalia Baranowska w szerszym zakresie wykorzystała protokoły Grupy Operacyjnej, N. Baranowska, op. cit.

10 S. Plokhy, op. cit., s. 123-132; G. Medvedev, The Truth about Chernobyl, New York 1991, s. $174-178$.

11 Dokument nr 71, Protokoł № 2 dennoho zasidannia uriadowoji komisiji SRSR po nadanniu medycznoji dopomohy, 2 V 1986, w: Czornobylśka trahedija. Dokumenty i materiały, red. N. Baranowska, Kyjiw 1996, s. 89-90; Dokument nr 74, Powidomlennia zastupnika hołowy Rady Ministriw URSR M. Orłyk orhanam włady i uprawlinnia Ukrajini pro uriadowu komisiju SRSR z medycznych problem, 3 V 1986, w: Czornobylśka trahedija..., s. 97. W publikacji tej znajdują się głównie dokumenty wytworzone przez władze Ukraińskiej SRS, dlatego wykorzystałem ją w ograniczonym zakresie. Normatywy wytworzone przez Grupę Operacyjną KC Komunistycznej Partii Ukrainy zostały zawarte w ostatnio wydanej pracy pt. Czornobyl. Dokumenty Operatywnoji 
$\mathrm{W}$ artykule zostaną poddane ocenie działania władz w pierwszych kilkunastu dniach po katastrofie, będących najbardziej newralgicznym okresem, w którym podejmowano kluczowe decyzje w kwestii m.in. ugaszenia pożaru, likwidacji skutków awarii, jak i ochrony zdrowia, życia mieszkańców oraz polityki informacyjnej w kraju i w przestrzeni międzynarodowej. W przypadku tej ostatniej istotną cezurę stanowiło pierwsze publiczne wystąpienie sekretarza generalnego KPZS Gorbaczowa, odnoszące się do Czarnobyla, które wyemitowano w telewizji 14 maja. Datę tę zdecydowałem się przyjąć jako cezurę zamykającą moje rozważania. Artykuł będzie zatem stanowił bilans działań władz sowieckich, jak również próbę odpowiedzi na pytanie, gdzie popełniono błędy i z czego one wynikały. Należy przy tym zaznaczyć, że będzie próbą jedynie częściową, bo taką być musi. Bazowałem bowiem tylko na części dokumentów, do których jest dziś dostęp. Wiele odpowiedzi mogą przynieść dokumenty dotąd nieujawnione, przede wszystkim protokoły z posiedzeń BP KZPR oraz Rady Ministrów ZSRS. Miejmy nadzieję, że okaże się to możliwe już za kilka lat.

Właściwe rozważania wypada poprzedzić krótkim wprowadzeniem na temat przyczyn awarii i jej przebiegu. To zagadnienie zostało bardzo dobrze opisane w literaturze, przede wszystkim anglosaskiej ${ }^{12}$. Po ukończeniu siłowni w Czarnobylu należało jeszcze przeprowadzić szereg testów bezpieczeństwa. Reaktor atomowy wymaga ciągłego chłodzenia wodą, szczególnie ten typu RBMK-1000, zainstalowany w Czarnobylu, ze względu na to, że jego moderatorem był grafit. Wodę do reaktora dostarczały pompy zasilane prądem wytworzonym przez należące do elektrowni turbiny. W razie zatrzymania pracy reaktora mogły być zasilane z zewnątrz, ale trzeba było brać pod uwagę także poważną awarię sieci elektrycznej. Na taką ewentualność uruchomione zostać miały generatory zasilane ropą w celu utrzymania pracy pomp wody. Na uruchomienie tych generatorów potrzebowano jednak kilkadziesiąt sekund. Istniała szansa, że wyłączający się reaktor wytworzy jeszcze trochę pary, która sprawi, że turbiny będą poruszały się przez jakiś czas. Liczono, że wytworzą $\mathrm{w}$ ten sposób dostateczną ilość energii, umożliwiającą pracę pomp przez newralgiczne kilkadziesiąt sekund (do czasu uruchomienia generatorów dieslowskich). To jednak należało sprawdzić w czasie testu wymagającego wyłączenia reaktora ${ }^{13}$. Pierwotnie test ten miał odbyć się w reaktorze nr 4 Czarnobylskiej Elektrowni Atomowej 25 kwietnia 1986 r. w czasie zmiany dziennej; pracownicy byli też wdrożeni w jego założenia. Tak się niestety nie stało. Tego dnia naczelny inżynier elektrowni Nikołaj Fomin został poproszony o przełożenie testu przez

grupy CK KPU (1986-1988), red. O.W. Bażan, O.G. Bażan, G.W. Boriak, S.I. Własenko, A. Smolij, Kyjiw 2017. Istnieje jeszcze edycja źródeł dotycząca następstw katastrofy czarnobylskiej w Republice Białoruś: Czernobyl 26 apriela 1986 - diekabr' 1991. Dokumienty i matieriały, red. W.I. Adamuszko et al., Minsk 2006.

12 Zob. m.in.: A. Higginbotham, op. cit.; A. Leatherbarrow, Chernobyl. 01:23:40, [b.m.w.] 2016;

S. Plokhy, op. cit.; P.P. Read, Czarnobyl. Zapis faktów, tłum. J. Kubowski, Warszawa 1996.

13 A. Leatherbarrow, op. cit., s. 54-55; S. Plokhy, op. cit., s. 63-64. 
kijowskie centrum dystrybucji energii elektrycznej. Okazało się bowiem, że jeden z reaktorów Południowoukraińskiej Elektrowni Atomowej (obwód mikołajowski) nieoczekiwanie odłączono od sieci elektrycznej. W obliczu wieczornego szczytu na zapotrzebowanie $\mathrm{w}$ energię test $\mathrm{w}$ Czarnobylu został przełożony na godziny nocne, kiedy do pracy przyszła mniej doświadczona i niewdrożona w test zmiana. Trudno w takiej sytuacji nie wierzyć, że historią w dużej mierze rządzi przypadek ${ }^{14}$.

Operatorzy rozpoczęli obniżanie mocy reaktora, chcąc doprowadzić do jego wyłączenia, co przewidziane zostało w założeniach testu. Jego moc spadała jednak dużo szybciej niż się tego spodziewano. Kierujący zmianą Anatolij Diatłow, mimo obiekcji formułowanych przez jego podwładnych, konsekwentnie parł do zrealizowania testu. Niestety przy dużym spadku mocy reaktor typu RBMK-1000 okazał się bardzo niestabilny i trudno było utrzymać nad nim kontrolę. Na dodatek działania operatorów, związane z przeprowadzanym testem, doprowadziły do spadku ilości wody w reaktorze. Była ona jednym $\mathrm{z}$ absorberów uwalnianych neutronów, w momencie kiedy jej zabrakło, zachodziła większa liczba reakcji atomowych, a co za tym idzie, moc reaktora zaczęła gwałtownie wzrastać. W tej sytuacji jeden z operatorów, Aleksandr Akimow, zaniepokojony sytuacją, wcisnął przycisk AZ-5, co oznaczało awaryjne wyłączenie reaktora. Wydawało się zatem, że zagrożenie zostało zażegnane, jednak wówczas ujawnił się jeden $\mathrm{z}$ fatalnych błędów konstrukcyjnych RBMK-1000. Przycisk sprawil, że 178 prętów kontrolnych zbudowanych $\mathrm{z}$ boru absorbującego neutrony zaczęło wchodzić do rdzenia reaktora. Ich czubek był jednak wykonany $z$ grafitu, który jeszcze bardziej zintensyfikował reakcje $\mathrm{w}$ reaktorze i doprowadził do wzrostu jego mocy i temperatury (30 $000 \mathrm{MWt}$ - 10 razy więcej niż dopuszczalna norma). O godz. 1.2326 kwietnia 1986 r. nastąpił pierwszy wybuch, a zaraz po nim kolejny. Żaden z nich nie był wybuchem jądrowym (reaktor rozsadziła nagromadzona para), ale uwolniły i jeszcze długo po wybuchu uwalniały ogromną ilość radionuklidów (wyparowało ok. 50 ton paliwa nuklearnego), które trafiły do atmosfery, gleby i wody ${ }^{15}$. Skażenie - głównie radioaktywnym cezem i jodem - objęło w mniejszym lub większym stopniu całą półkulę północną. Największe szkody wyrządziło jednak na obszarach w promieniu kilkuset kilometrów od elektrowni.

Oczywiście nikt wówczas nie znał przyczyn i skali awarii. Co więcej, Diatłow, a za nim Fomin i dyrektor elektrowni Wiktor Briuchanow utrzymywali, że reaktor pozostał nietknięty, a źródłem wybuchu były zbiorniki wody. Podawali też znacznie zaniżony poziom promieniowania na terenie siłowni, co wynikało z ograniczeń skali posiadanych przez nich aktualnie dozymetrów. Takie też raporty były wysyłane do Kijowa i Moskwy ${ }^{16}$. Jako pierwszy w Moskwie o wypadku dowiedział się Władimir Marin zajmujący się kwestiami energetyki nuklearnej z ramienia KPZS.

\footnotetext{
14 A. Leatherbarrow, op. cit., s. 56; S. Plokhy, op. cit., s. 70-71.

15 G. Medvedev, op. cit., s. 70-76; A. Leatherbarrow, op. cit., s. 60-67; S. Plokhy, op. cit., s. 80-86.

16 A. Leatherbarrow, op. cit., s. 68-69; G. Medvedev, op. cit., s. 104, 117-122.
} 
W telefonicznej rozmowie Briuchanow uspokajał go, że sytuacja jest pod kontrolą ${ }^{17}$. Jeszcze 26 kwietnia, najprawdopodobniej kilka godzin po wybuchu, Ministerstwo Energetyki i Elektryfikacji ZSRS przesłało do KC KPZS krótką notatkę zawierającą najważniejsze informacje o awarii. Wiceminister Ołeksij Makuchin pisał w niej zdawkowo o wybuchu i pożarze. Wzmianka o chłodzeniu reaktora każe zaś twierdzić, że w Moskwie przyjęto wersję usłyszaną od dyrektora elektrowni, zgodnie z którą reaktor nie został zniszczony. Oprócz tego Makuchin przywoływał opinię Ministerstwa Zdrowia, co oznaczałoby, że już poczyniono pierwsze konsultacje międzyresortowe. Według niej podjęcie specjalnych środków, w tym ewakuacji pobliskiej Prypeci, było zbędne. Oczywiście należy przy tym pamiętać, że resort zdrowia kierował się zaniżonymi danymi o promieniowaniu, które przysyłało kierownictwo elektrowni ${ }^{18}$. Jak więc widać, 26 kwietnia rano sowieckie kręgi władzy były dalekie od paniki i miały do tego pełne prawo, biorąc pod uwagę docierające do nich uspokajające informacje. O godz. 6 rano o wypadku dowiedział się premier Ryżkow, który z kolei zatelefonował do Gorbaczowa. Sekretarz generalny zapowiedział specjalne posiedzenie BP, ale dopiero na poniedziałek 28 kwietnia $^{19}$, widocznie posiadane przez niego wówczas informacje nie nakazywały pośpiechu i przerywania weekendu członkom BP. Sam w swoich wspomnieniach podkreślał, że w pierwszym dniu po wybuchu nie było świadomości, że reaktor eksplodował, a do atmosfery dostała się duża ilość radionuklidów ${ }^{20}$.

26 kwietnia rano zaczęły napływać meldunki m.in. z wojska, oceniające sytuację jako poważną. Przed południem premier Ryżkow powołał Komisję Rządową, $\mathrm{z}$ wicepremierem Szczerbiną na czele, której celem było zbadanie sytuacji i podjęcie odpowiednich działań. W jej składzie znaleźli się przede wszystkim specjaliści z różnych resortów oraz Akademii Nauk, m.in. minister energetyki i elektryfikacji Anatolij Majoriec, jego zastępca Giennadij Szaszarin, wspomniany już Marin, zastępca dyrektora Instytutu Energii Atomowej im. Igora Kurczatowa w Moskwie Walerij Legasow oraz jeden z projektantów reaktora - Konstantin Poluszkin. Członkowie Komisji sukcesywnie przybywali na miejsce 26 kwietnia. Kilku z nich przeleciało helikopterem nad reaktorem i mogło z bliska zobaczyć skalę zniszczeń $^{21}$. Na miejscu od przedstawicieli lokalnych służb dowiedzieli się o wyższym, niż zakładano, promieniowaniu oraz pierwszych jego ofiarach. Generał Władimir Pikalow, dowódca wojsk chemicznych, osobiście pojechał na teren elektrowni i tam sam zmierzył rzeczywisty poziom promieniowania. Oczywiście sytuacja

17 N. Daniloff, op. cit., s. 120.

18 Srocznoje doniesienije, 26 IV 1986, RGANI, f. 89, op. 54, d. 88 (kopia ze strony: https:// nsarchive2.gwu.edurusPerestroikaChernobyl.html [dostęp: 18.02.2019]).

19 N. Daniloff, op. cit., s. 120.

20 S. Plokhy, op. cit., s. 121; A. Higginbotham, op. cit., s. 151; Wywiad z Michaiłem Gorbaczowem, http://news.bbc.co.uk/2/hi/europe/4918940.stm (dostęp: 12.07.2018).

${ }^{21}$ N. Baranowska, op. cit., s. 31; S. Plokhy, op. cit., s. 123, 130; N. Daniloff, op. cit., s. 121-122; G. Medvedev, op. cit., s. 127, 153-155, 177. 
była dużo poważniejsza, niż widziało to kierownictwo elektrowni. Członkowie Komisji przekazali hiobową wieść do Moskwy ok. godz. 7.00 27 kwietnia. Wtedy też Szczerbina - za radą funkcjonariuszy obrony cywilnej - podjął decyzję o ewakuacji mieszkańców Prypeci w godzinach popołudniowych. Oczywiście nie mógł tego zrobić bez konsultacji z Moskwą, jego decyzję zatwierdził premier ZSRS. Już wcześniej Ryżkow dał zgodę premierowi Ukraińskiej SRS Ołeksandrowi Liaszce na przygotowanie 1200 autobusów i 240 ciężarówek na wypadek konieczności ewakuowania ludności. W nocy z 26 na 27 kwietnia wyruszyły w kierunku Prypeci, by znaleźć się tam wcześnie rano 27 kwietnia. Ostatecznie do ewakuacji doszło wczesnym popołudniem, akcja przebiegła niezwykle szybko i sprawnie, w zaledwie kilka godzin udało się ewakuować ponad 44 tys. mieszkańców ${ }^{22}$. Oczywiście akcja była i tak już nieco spóźniona, mieszkańcy Prypeci, w tym wiele dzieci, przyjęli szkodliwą dla zdrowia dawkę promieniowania. Szczerbina i jego Komisja podjęli też - za radą specjalistów - kolejną ważką decyzję. Na zniszczony reaktor miały zostać zrzucone tony piasku i boru w celu ugaszenia pożaru. Zadanie to zlecono załogom wojskowych śmigłowców ${ }^{23}$.

Nie wiadomo, jakie konkretnie wiadomości napływały na Kreml. Jak wspomniałem, 27 kwietnia rano trafiły tam informacje od Komisji Rządowej. Na pewno we wczesnych godzinach popołudniowych do KC dotarła informacja od szefa Państwowego Komitetu Hydrometeorologii i Ochrony Środowiska Jurija Izraela. Jego raport bazujący na pomiarach dokonanych 26 i 27 kwietnia był już znacznie bardziej alarmujący niż pierwsze doniesienia. Izrael pisał o wysokim stopniu zanieczyszczenia atmosfery radioaktywnymi izotopami, które wiatr rozniósł we wszystkich kierunkach, przewidywał także, że ich obecność zostanie odnotowana za granicą ${ }^{24}$. Po tym raporcie kierownictwo partii oraz rząd na pewno nie mogły już lekceważyć wypadku w Czarnobylu. Przed sowieckim przywództwem dopiero zaczęła wyłaniać się skala problemu, z którym przyszło im się zmierzyć. Stało się też jasne, że nie ograniczy się on wyłącznie do obszaru ZSRS, ale będzie miał również wymiar międzynarodowy ${ }^{25}$.

BP zebrało się zgodnie z dyspozycją Gorbaczowa 28 kwietnia. Wtedy to najważniejszy organ władzy w ZSRS podjął dyskusję o katastrofie. Najpierw zebrani

${ }^{22} \mathrm{~W}$ kolejnych dniach podjęto decyzję o ewakuowaniu mieszkańców w promieniu $30 \mathrm{~km}$ od elektrowni, oznaczało to wysiedlenie kolejnych kilkudziesięciu tysięcy ludzi, S. Plokhy, op. cit., s. 191-192.

${ }^{23}$ N. Baranowska, op. cit., s. 35; G. Medvedev, op. cit., s. 177-178; S. Plokhy, op. cit., s. 118, 135, 139-141, 151-154; A. Higginbotham, op. cit., s. 190-191; E. Geist, op. cit., s. 118-119; Dokument nr 56, Powidomlennia Ministerstwa Awtotransportu URSR CK Kompartiji Ukrajiny pro zachody szczo do ewakuaciji naselennia m. Prypjati, 27 IV 1986, w: Czornobylśka trahedija..., s. 76-77; Dokument nr 58, Powidomlennia MWS URSR CK Kompartiji Ukrajiny pro chid ewakuaciji naselennia iz zony awariji, 28 IV 1986, w: Czornobylśka trahedija..., s. 78.

${ }^{24}$ O posledstwijach awarii na Czernobylskoj AES, 27 IV 1986, RGANI, f. 89, op. 53, d. 36 (kopia ze strony: https://nsarchive2.gwu.edurusPerestroikaChernobyl.html [dostęp: 18.02.2019]).

25 N. Daniloff, op. cit., s. 122. 
wysłuchali raportu Władimira Dołgicha, sekretarza KC odpowiedzialnego m.in. za energetykę nuklearną. Dołgich poinformował o wybuchu oraz podał odnotowane pomiary promieniowania (1000 rentgenów w elektrowni, 230 milirentgenów w mieście). Powiedział o ewakuacji i zasypywaniu reaktora piaskiem, gliną i innymi materiałami, zaznaczając przy tym, że wrzucono dopiero 60 worków z zaplanowanych 1800. Członkowie BP usankcjonowali wcześniejszą decyzję o powołaniu Komisji Rządowej, uznali, że będzie ona odpowiedzialna za likwidację skutków awarii przy wsparciu organów partyjnych i państwowych ${ }^{26}$. Cele, które wyznaczało BP w związku z katastrofą, były mocno ogólnikowe: ustalenie przyczyny awarii, stworzenie właściwych warunków bytowych ewakuowanym, utrzymanie porządku i dyscypliny ${ }^{27}$.

$\mathrm{Na}$ wspomnianym posiedzeniu Gorbaczow postulował, aby sformułować informację dla opinii publicznej o wybuchu i podejmowanych działaniach w celu ustalenia jego następstw. Jak jednak podkreślał Andriej Gromyko, powinna ona być skonstruowana $w$ taki sposób, aby nie spowodowała nadmiernego niepokoju i paniki. Opracowano więc komunikat sygnowany przez Radę Ministrów ZSRS: „W Czarnobylskiej Elektrowni Atomowej doszło do awarii, uszkodzony został jeden $\mathrm{z}$ reaktorów. Podjęto działania w celu likwidacji następstw awarii. Ofiarom udzielono pomocy. Powołano Komisję Rządową"28. Nie sposób nie dostrzec, że komunikat był bardzo zdawkowy. Co prawda informowano w nim o wypadku, ale właściwie niewiele ponadto. Władze z jednej strony nie zbyły całkowitym milczeniem tego, co się wydarzyło na Ukrainie, ale $\mathrm{z}$ drugiej strony pominęły wiele istotnych faktów, które były już im znane. Dobry przykład stanowi kwestia ofiar. Komunikat nic nie mówił o ich liczbie, nie wspominał również o zabitych, co więcej fakt, że udzielana była im pomoc, mógłby wskazywać, że nie ma tu mowy o ofiarach śmiertelnych. Nie pojawiła się również wzmianka o ewakuacji ludności, poziomie promieniowania czy podstawowych środkach ostrożności. Widać więc wyraźnie, że celowo unikano takich faktów, które mogłyby wzbudzić niepokój mieszkańców kraju. Co więcej, ostatecznie ograniczono zasięg informacji. Na posiedzeniu Politbiura uznano, że zostanie ona przedstawiona w telewizyjnym wydaniu dziennika „Wremia” 28 kwietnia oraz w gazecie „Izwiestija” i lokalnej prasie ukraińskiej następnego dnia. Faktycznie w wieczornym programie „Wremia” można było usłyszeć przytoczony komunikat, ale była to dopiero dwudziesta pierwsza informacja podana w tym wydaniu wiadomości. Podobnie komunikat przekazała prasa. Następnego dnia opublikowały go niektóre gazety

26 Wypiska iż protokoła № 8 zasiedanija Politbiuro CK KPSS ot 28 apriela 1986 g., 28 IV 1986, RGANI, f. 89, op. 53, d. 1 (kopia ze strony: https://nsarchive2.gwu.edurusPerestroikaChernobyl. html [dostęp: 18.02.2019]).

27 Ibidem; R.G. Pichoja, Sowietskij Sojuz. Istorija własti 1945-1991, Nowosybirsk 2000, s. 430.

${ }^{28}$ Soobszczenije dla pieczati: ot Sowieta Ministrow SSSR, 28 IV 1986, RGANI, f. 89, op. 53, d. 1 (kopia ze strony: https://nsarchive2.gwu.edurusPerestroikaChernobyl.html [dostęp: 18.02.2019]); R.G. Pichoja, op. cit., s. 431. 
ukraińskie, ale w taki sposób, że tylko bardzo uważny czytelnik mógł go dostrzec. Przykładowo „Robotniczyja Hazeta” umieściła go pomiędzy wynikami meczów piłkarskich a relacją z turnieju szachowego. Dopiero 30 kwietnia komunikat został przedrukowany przez moskiewską „Izwiestiję”, w tym wypadku również można było odnieść wrażenie, że to mało istotna i niegodna uwagi wzmianka. Ludności nie udzielono zatem rzetelnej i pełnej informacji, nadrzędnym celem okazała się nie jej ochrona, ale lęk przed wybuchem paniki ${ }^{29}$.

Następnego dnia (29 kwietnia) BP zebrało się ponownie i wysłuchało kolejnego raportu Dołgicha. Można więc zauważyć, że co najmniej od 28 kwietnia sytuacja była traktowana już z pełną powagą przez moskiewskie centrum władzy. Świadczyło o tym również powołanie wspomnianej Grupy Operacyjnej BP KC KPZS, w skład której weszli: Ryżkow (premier), Jegor Ligaczow, Witalij Worotnikow (premier Rosyjskiej FSRS), Wiktor Czebrikow (szef KGB), Dołgich, Siergiej Sokołow (minister obrony ZSRS) i Aleksandr Własow (minister spraw wewnętrznych Rosyjskiej FSRS). Grupie powierzono zadania podobne do tych, które wymieniono poprzedniego dnia: ustalenie najważniejszych źródeł promieniowania, monitorowanie poziomu skażenia gleby i powietrza, organizacja wszelkiej pomocy, w tym medycznej, dla ludności ze strefy dotkniętej skażeniem. Kierownictwo partii nie pozostawiało też najmniejszej wątpliwości, że to Grupa Operacyjna ma wydawać polecenia Komisji Rządowej, a nie na odwrót. Należy też pamiętać o samej specyfice systemu sowieckiego, w którym ważniejszą rolę odgrywało kierownictwo partii, a nie konstytucyjne organy rządowe. Sam skład obu grup wskazuje też na ich znaczenie. Mimo iż Grupa Operacyjna działała z ramienia partii, to $w$ jej gronie znaleźli się przede wszystkim ważni ministrowie, a na jej czele stanął premier ZSRS. Nie ulega kwestii, że Grupa skupiła w swoich rękach największą władzę w sprawach związanych $\mathrm{z}$ katastrofą. Zgodnie z rezolucją Politbiura mogła ona wydawać dyspozycje nie tylko Komisji Rządowej, ale wszystkim partyjnym, rządowym oraz naukowym instytucjom $w$ kraju ${ }^{30}$. Można przyjąć, że od tej pory rola samego BP zawężała się w zasadzie do akceptowania najważniejszych postanowień Grupy Operacyjnej ${ }^{31}$. Wydaje się zatem, że dla prześledzenia dalszych ruchów władz nawet istotniejsze

29 A. Higginbotham, op. cit., s. 211; Wypiska iż protokoła № 8 zasiedanija Politbiuro CK KPSS ot 28 apriela 1986 g., 28 IV 1986, RGANI, f. 89, op. 53, d. 1 (kopia ze strony: https://nsarchive2. gwu.edurusPerestroikaChernobyl.html [dostęp: 18.02.2019]); „Izwiestija” (30 IV 1986).

30 Dokument nr 222, Resolution of the Central Commitee, April 29, on additional measures to be taken concerning the damage caused by the Chernobyl accident, w: Revelations from the Russian Archives..., s. 505.

${ }^{31}$ Przykładem może być rezolucja KC KPZS z 5 maja, w której KC zatwierdza dotychczasowe działania Grupy Operacyjnej, Postanowlenije CK KPSS, 5 V 1986, RGANI, f. 89, op. 53, d. 3 (kopia ze strony: https://nsarchive2.gwu.edurusPerestroikaChernobyl.html [dostęp: 18.02.2019]) czy też protokół z posiedzenia BP KC KPZS z 15 maja, na którym członkowie Biura wysłuchali raportu Grupy Operacyjnej i zatwierdzili jej propozycje w najważniejszych kwestiach związanych z awarią, Postanowlenije Politbiuro CK KPSS ot 15 maja 1986 g., w: Czernobylskaja katastrofa w dokumientach Politbiuro CK KPSS, „Rodina” (1992), nr 1, s. 85. 
od protokołów BP (którymi nie dysponujemy) są dostępne protokoły z posiedzeń wspomnianej Grupy. Pozostaje jeszcze pytanie, jaką zatem rolę przewidywano dla komisji Szczerbiny? Do 29 kwietnia była istotnym ogniwem decyzyjnym, pod którego wpływem podjęto m.in. niezwykle ważną decyzję o ewakuacji. Wydaje się, że później stanowiła przede wszystkim zaplecze eksperckie dla Grupy Operacyjnej. Ta podejmowała decyzje polityczne, ale w jej gronie nie było specjalistów $\mathrm{z}$ dziedziny energetyki jądrowej mogących oceniać sytuację i wybierać najlepsze rozwiązania. To mogła natomiast robić ekipa Szczerbiny, która na dodatek pracowała na miejscu katastrofy.

Na posiedzeniu BP uzgodniono kolejny komunikat dla obywateli ZSRS, tym razem dostarczał on więcej szczegółów, ale również pozbawiony był tych detali, które mogłyby zaniepokoić ludność. Poinformowano o działalności komisji Szczerbiny złożonej z wysokiej klasy naukowców i specjalistów. Dodawano, że wybuch zniszczył częściowo budynek, w którym znajdował się reaktor, w wyniku czego uwolniła się pewna ilość radioaktywnego materiału. Przyznawano się tym razem do dwóch ofiar śmiertelnych i ewakuowania mieszkańców najbliższych okolic elektrowni. Powtórzono jeszcze formułkę o pracach nad usuwaniem skutków awarii oraz udzielaniu niezbędnej pomocy ofiarom awarii. Uspokajano przy tym, że sytuacja radiacyjna na terenie elektrowni i jej najbliższego otoczenia ustabilizowała się ${ }^{32}$. W porównaniu z poprzednim, niezwykle zdawkowym komunikatem ten przynosił więcej konkretnych informacji. Szczególną uwagę zwraca wiadomość o ofiarach śmiertelnych i ewakuacji. Mimo iż było jasne, że wzbudzi to niepokój mieszkańców, przede wszystkim Ukraińskiej SRS, zdecydowano się na podanie również złych informacji. Jednocześnie komunikat miał za zadanie uspokoić obywateli i stworzyć wrażenie, że sytuacja się poprawia i jest pod pełną kontrolą najlepszych specjalistów. Warto także zwrócić uwagę, że po raz kolejny nie podano zaleceń, które mogłyby uchronić ludzi, przede wszystkim dzieci, przed niepotrzebną ekspozycją na promieniowanie radioaktywne. W dalszym ciągu widoczna była niechęć do radykalnych posunięć mogących wywołać niekontrolowany wybuch paniki.

$\mathrm{Na}$ tym samym posiedzeniu podjęto jeszcze jedną niezwykle istotną kwestię, która nie została poruszona na pierwszym spotkaniu poprzedniego dnia. Chodziło o zasadnicze pytanie, co i jak powiedzieć rządom innych krajów. Szybko stało się jasne, że katastrofa nie jest jedynie problemem wewnętrznym. Wiatr roznosił radioaktywny pył po całym kontynencie. W pierwszym rzędzie zaniósł go w kierunku północno-zachodnim, skażając tereny Białoruskiej SRS, Polski i docierając w końcu do Skandynawii. Podwyższenie poziomu radioaktywności odnotowano w Polsce i w Szwecji 28 kwietnia. Szwedzka dyplomacja próbowała pozyskać informacje od strony sowieckiej, ale bezskutecznie ${ }^{33}$. Nieco lepiej poszło polskiemu wicepremierowi Zbigniewowi Szałajdzie, który wieczorem 28 kwietnia zdołał uzyskać

${ }^{32}$ Dokument nr 222..., s. 506.

${ }^{33}$ S. Plokhy, op. cit., s. 175; A. Leatherbarrow, op. cit., s. 162. 
bezpośrednie połączenie z Ryżkowem. Premier ZSRS, co najważniejsze, przyznał, że doszło do awarii elektrowni jądrowej w ich kraju, ale nie mógł lub nie chciał udzielić dalszych informacji ${ }^{34}$. Tego typu zapytania płynęły pewnie też $\mathrm{z}$ innych stolic. Dla sowieckiego kierownictwa stało się oczywiste, że sprawy awarii nie można trzymać dłużej w tajemnicy. Trzeba było udzielić światu jakiegokolwiek wyjaśnienia, nawet jeśli miałoby się opierać na skąpej jak dotychczas wiedzy o wypadku, jego przyczynach i charakterze.

Treść komunikatu dla rządów innych krajów bardzo przypominała informację przygotowaną dla mieszkańców ZSRS. Z tą jednak różnicą, że za granicę przekazano wieści o rozprzestrzenianiu się radiacji w różnych kierunkach i dodawano, że poziom promieniowania przekracza dopuszczalne normy, choć nie $\mathrm{w}$ takim stopniu, by wymagało to specjalnych środków ochrony ludności ${ }^{35}$. Ta z pozoru błaha różnica była jednak dość istotna. Obywateli ZSRS nie powiadomiono, że sytuacja radiacyjna odstaje od norm, ponadto przemilczano kwestię zagrożenia promieniowaniem dla obszarów bardziej oddalonych od Czarnobyla. Własnym obywatelom informacje podawano dużo ostrożniej: wiadomości były okrojone ze wszystkiego, co mogło wzmagać panikę w ZSRS. Po raz kolejny obawa przed niepokojem społecznym okazała się silniejsza niż troska o dobro mieszkańców kraju.

Oficjalnych informacji krajom ościennym ZSRS udzielił zatem 29 kwietnia, trzy dni po awarii. Było to przedmiotem pretensji formułowanych pod adresem Moskwy $^{36}$. Trzeba przy tym dodać, że dalej nie precyzowano, ile i jakiego typu substancji radioaktywnych mogło się wydzielić. To natomiast - przynajmniej w pewnym przybliżeniu - było znane sowieckim specjalistom od energetyki atomowej i mogło zostać ujęte w wydawanych komunikatach. Zwróćmy także uwagę, że pierwsza oficjalna informacja na temat awarii została ogłoszona 28 kwietnia, można było zatem już wtedy przesłać ją rządom innych państw. Gwoli ścisłości trzeba dodać, że korespondenci i dyplomaci pracujący w Moskwie i tak pewnie błyskawicznie przekazali ją do swoich stolic. Niemniej jednak na pewno dzień wcześniej można było wykorzystać kanały dyplomatyczne do przesłania oficjalnej, nawet mocno ogólnikowej, informacji. Brak wcześniejszych działań tego typu należy jednak tłumaczyć nie tylko niechęcią władz sowieckich do ujawniania faktu katastrofy, ale też brakiem świadomości o jej skali i zasięgu. To spowodowało opóźnienie w podjęciu adekwatnych środków zarówno na miejscu katastrofy, jak i w stosunku do obywateli własnego i innych krajów. Trzeba też w końcu zwrócić uwagę na jeszcze jeden istotny aspekt międzynarodowy. Nie istniały wówczas żadne

${ }^{34}$ Raport Komisji Rządowej pod przewodnictwem Wiceprezesa Rady Ministrów PRL Zbigniewa Szałajdy, czerwiec 1986, Archiwum Akt Nowych w Warszawie, Urząd Rady Ministrów, Biuro Prasowe Rządu, sygn. 222/372, s. 24-25; Rozmowa ze Zbigniewem Szałajdą, 28 I 2019, nagranie w zbiorach autora.

35 Dokument nr 222..., s. 506-507.

36 [Informacja dla KC KZPR], 30 IV 1986, RGANI, f. 89, op. 53, d. 3 (kopia ze strony: https:// nsarchive2.gwu.edurusPerestroikaChernobyl.html [dostęp: 18.02.2019]). 
regulacje międzynarodowe zobowiązujące jakiekolwiek państwo do szczegółowego informowania społeczności międzynarodowej o wypadkach tego typu. Z formalnego punktu widzenia Związek Sowiecki nie pogwałcił więc żadnej konwencji. Takie regulacje zostały opracowane i wdrożone z inicjatywy Międzynarodowej Agencji Energii Atomowej (MAEA) dopiero po doświadczeniu katastrofy czarnobylskiej ${ }^{37}$.

29 kwietnia jest ważną cezurą nie tylko ze względu na kontekst międzynarodowy. Tego dnia po raz pierwszy zebrała się Grupa Operacyjna BP KC KPZS, która przejęla faktyczne kierownictwo nad wszelkimi sprawami związanymi z katastrofą. Spotkanie rozpoczął Dołgich, referując bieżącą sytuację. Następnie zebrani wysłuchali Izraela, którego zobowiązali do dostarczenia jasnych i wiarygodnych informacji o promieniowaniu. Warto $\mathrm{w}$ tym miejscu zauważyć, że trzy dni po katastrofie $\mathrm{w}$ dalszym ciągu służby nie były w stanie precyzyjnie określić poziomu skażenia i jego obszaru, co wyraźnie irytowało władze polityczne. Izrael został zobowiązany, aby udać się do Czarnobyla i na miejscu podjąć właściwe działania. Podobnie rzecz miała się z opieką medyczną nad ludnością zamieszkującą najbliższe rejony elektrowni. Grupa Operacyjna wyraziła daleko idące niezadowolenie $\mathrm{z}$ dotychczasowego przebiegu prac na tym polu i poleciła ministrowi ochrony zdrowia ZSRS Siergiejowi Burenkowowi również udać się na miejsce katastrofy. Grupa nakazała także mobilizację obrony cywilnej oraz wojsk chemicznych ${ }^{38}$. Specjaliści mieli natomiast skupić się na ustaleniu przyczyny awarii, by uniknąć - jak podkreślano - powtórki tego typu katastrofy w przyszłości ${ }^{39}$.

Kolejne spotkania tego gremium odbywały się niemal codziennie, co jest kolejnym świadectwem tego, że na Kremlu wreszcie zrozumiano powagę sytuacji. Każde zebranie rozpoczynało się od omówienia sytuacji radiacyjnej w europejskiej części ZSRS. Był to element spędzający sen z powiek sowieckiej elicie przynajmniej w pierwszym okresie po awarii. Poważnie brano pod uwagę ewakuację Kijowa, gdyby sytuacja ulegała dalszemu pogorszeniu. Z biegiem czasu, gdy kolejne meldunki potwierdzały jednak obniżanie się poziomu promieniowania, temat sytuacji radiacyjnej zszedł siłą rzeczy na dalszy plan. W pierwszym rzędzie uwaga członków Grupy Operacyjnej skupiona była na odkażaniu najbliższych okolic elektrowni (w co zaangażowana została przede wszystkim Armia Sowiecka) oraz zapewnieniu właściwej opieki medycznej dla ludności. Mimo zdyscyplinowania Burenkowa na pierwszym zebraniu, dalej zauważano istotne mankamenty

37 D.R. Marples, The Social Impact of the Chernobyl Disaster, Houndmills-Basingstoke-London 1988, s. 246-247; Report on visit to the Soviet Union from 5 to 9 May 1986, [b.d.], Archiwum Międzynarodowej Agencji Energii Atomowej w Wiedniu (dalej: Archiwum MAEA), GOVINF 496, s. nlb.

${ }^{38}$ Do końca maja w rejonie katastrofy pracowało już 10 tys. żołnierzy wojsk chemicznych, N. Baranowska, op. cit., s. 32.

39 Protokoł № 1 zasiedanija Opieratiwnoj gruppy Politbiuro CK KPSS po woprosam, swiazannym s likwidacyjej posledstwij awarii na Czernobylskoj AES, 29 IV 1986, w: A. Jaroszynska, Czernobyl. Sowierszenno Siekrietno..., s. 251-252. 
w pracy służb medycznych. W tej sytuacji Grupa powołała do życia kolejną komisję, pod kierownictwem wiceministra zdrowia Szczepina, co miało usprawnić opiekę medyczną na terenach, które najbardziej odczuwały skutki awarii. Szczepin został także zobowiązany do codziennego raportowania o liczbie hospitalizowanych, $\mathrm{z}$ wyszczególnieniem dzieci oraz osób dotkniętych chorobą popromienną ${ }^{40}$. Od tej pory temat ten regularnie pojawiał się na posiedzeniach Grupy Operacyjnej. Było to o tyle istotne, gdyż dawało wyobrażenie o skutkach zdrowotnych w pierwszych dniach po katastrofie. Ponadto umożliwiało ocenę sytuacji oraz dalsze kroki, które należałoby podjąć, np. ewakuację kolejnych obszarów kraju.

Na posiedzeniu 1 maja Grupa podjęła decyzję o zmianie składu Komisji Rządowej, co było uwarunkowane narażeniem jej dotychczasowych członków na przyjęcie zbyt dużej dawki promieniowania. Od 2 maja Szczerbinę zastąpił członek KC i wicepremier Iwan Siłajew. Rozważano możliwość zorganizowania konferencji prasowej dostępnej również dla korespondentów zagranicznych. Zdecydowano, że jej data ustalona będzie wówczas, gdy poznane zostaną wszystkie niezbędne szczegóły ${ }^{41}$. Widocznie sowieccy politycy uznali, że nie ma sensu organizować konferencji na etapie, w którym nie będą w stanie odpowiedzieć na wiele z zadawanych pytań, np. dotyczących liczby ofiar i hospitalizowanych, albo precyzyjnie określić zasięgu i skali skażenia. Te wszystkie rzeczy stanowiły w dalszym ciągu przedmiot analizy. Nie przeszkadzało to jednak w uprawianiu propagandy względem własnego społeczeństwa. Członkowie BP nakazali bowiem, aby na miejsce wyjechała grupa sowieckich dziennikarzy celem przygotowania materiału mówiącego o tym, że w zasadzie w rejonie katastrofy wszystko funkcjonuje jak dawniej. $Z$ jednej strony przyznawano więc, że brakuje jeszcze dostatecznych informacji, ale $\mathrm{z}$ drugiej strony mieszkańcom ZSRS a priori usiłowano wmówić, że nic się właściwie nie stało i wszystko jest $\mathrm{w}$ porządku ${ }^{42}$. W tym kontekście nie dziwi również decyzja o nieodwoływaniu tradycyjnych pochodów pierwszomajowych i udziale w nim dzieci, mimo iż władze sowieckie wiedziały, że poziom promieniowania przekracza dopuszczalne normy. Pochody więc odbyły się jak zawsze, również w oddalonym o ok. $130 \mathrm{~km}$ od Czarnobyla ponaddwumilionowym Kijowie. Miał to być sygnał dla społeczeństwa i świata, że sytuacja jest na tyle unormowana, że nie wymaga nadzwyczajnym kroków, takich jak choćby wstrzymanie pochodów.

40 Protokoł № 2 zasiedanija Opieratiwnoj gruppy Politbiuro CK KPSS po woprosam, swiazannym s likwidacyjej posledstwij awarii na Czernobylskoj AES, 30 IV 1986, w: A. Jaroszynska, Czernobyl. Sowierszenno Siekrietno..., s. 254; Protokoł № 3 zasiedanija Opieratiwnoj gruppy Politbiuro CK KPSS po woprosam, swiazannym s likwidacyjej posledstwij awarii na Czernobylskoj AES, $1 \mathrm{~V}$ 1986, w: A. Jaroszynska, Czernobyl. Sowierszenno Siekrietno..., s. 256; Protokoł № 8 zasiedanija Opieratiwnoj gruppy Politbiuro CK KPSS po woprosam, swiazannym s likwidacyjej posledstwij awarii na Czernobylskoj AES, 7 V 1986, w: A. Jaroszynska, Czernobyl. Sowierszenno Siekrietno..., s. 277.

41 Protokoł № 3..., s. 256-257.

${ }^{42}$ Ibidem, s. 257. 
Sygnał ten jednak został wysłany z narażeniem zdrowia mieszkańców Kijowa i wielu innych miast. W wywiadzie udzielonym po 20 latach Gorbaczow przyznał, że należało wówczas odwołać pochody, a czynnikiem, który wpłynął na decyzję, była obawa przed wybuchem paniki w kilkumilionowym mieście ${ }^{43}$.

Na czwartym zebraniu Grupy Operacyjnej Ligaczow i Ryżkow zdali sprawozdanie ze swojego krótkiego pobytu w Czarnobylu 2 maja. Z ich wypowiedzi przebijało zadowolenie, pozytywnie oceniali prace mające na celu likwidację skutków awarii, $w$ dalszym ciągu jednak dostrzegali niedociągnięcia w kwestii opieki medycznej. $Z$ tego też powodu na zebranie został zaproszony Szczepin, który kolejny raz musiał się tłumaczyć z działalności służb medycznych. Stało się jasne, że mimo upływu kolejnych kilku dni resort zdrowia nie radził sobie z sytuacją. W związku z tym sowieckie kierownictwo nakazało również siłowym wojskowym zorganizowanie opieki medycznej dla ewakuowanej ludności oraz poleciło Ministerstwu Handlu Zagranicznego zakup za granicą niezbędnego sprzętu i leków. Dopiero takie posunięcia sprawiły, że sytuacja na tym odcinku poprawiła się w odczuwalny sposób. Wojsko znacząco wsparło Ministerstwo Ochrony Zdrowia przede wszystkim w zakresie diagnozowania chorób związanych z promieniowaniem ${ }^{44}$.

Członkowie Grupy zdecydowali także, że odbędą się rozmowy z ambasadorami krajów socjalistycznych w kwestiach odnoszących się do awarii. Spotkanie takie zaplanowano na 3 maja, ale nie wykluczano kolejnych $\mathrm{w}$ razie zaistnienia potrzeby. Jednocześnie władze sowieckie nie miały zamiaru szerzej informować dyplomatów zachodnich, w przeciwieństwie do tych z krajów „zaprzyjaźnionych”. Na posiedzeniu Sekretariatu KC 5 maja nie tylko poparto wcześniejszą decyzję Grupy Operacyjnej, ale jeszcze bardziej dobitnie podkreślono, aby systematycznie informować ambasadorów krajów socjalistycznych, a tylko od czasu do czasu przedstawicieli krajów kapitalistycznych oraz tych z Trzeciego Świata. Na tym etapie ujawniła się zatem dość wyraźna różnica w traktowaniu poszczególnych przedstawicielstw zagranicznych w ZSRS. Dyplomaci z „wrogiego” obozu byli zdani więc na własne źródła lub te oficjalne. Okazją do tego mogła być wspomniana konferencja prasowa, dostępna również dla dziennikarzy zagranicznych, którą ustalono na 6 maja $^{45}$. W jej trakcie sowieccy politycy mówili o awarii, nie szczędząc jednak przy tym słów krytyki pod adresem państw zachodnich, które oskarżali o szerzenie

${ }^{43}$ S. Plokhy, op. cit., s. 184-188; R.G. Pichoja, op. cit., s. 433.

44 Protokoł № 4 zasiedanija Opieratiwnoj gruppy Politbiuro CK KPSS po woprosam, swiazannym s likwidacyjej posledstwij awarii na Czernobylskoj AES, 3 V 1986, w: A. Jaroszynska, Czernobyl. Sowierszenno Siekrietno..., s. 259-260; Protokoł № 5 zasiedanija Opieratiwnoj gruppy Politbiuro CK KPSS po woprosam, swiazannym s likwidacyjej posledstwij awarii na Czernobylskoj AES, 4 V 1986, w: A. Jaroszynska, Czernobyl. Sowierszenno Siekrietno..., s. 264-265.

45 Protokoł № 4..., s. 261-262; [Informacja dla KC KZPR], 3 V 1986, RGANI, f. 89, op. 53, d. 3 (kopia ze strony: https://nsarchive2.gwu.edurusPerestroikaChernobyl.html [dostęp: 18.02.2019]); Postanowlenije CK KPSS, 5 V 1986, ibidem (kopia ze strony: https://nsarchive2.gwu.edurusPerestroikaChernobyl.html [dostęp: 18.02.2019]). 
paniki i wyolbrzymianie zagrożenia. Inna rzecz, że konferencja była nadzwyczaj krótka, została zakończona po godzinie, mimo iż wielu korespondentów chciało zadawać jeszcze pytania ${ }^{46}$.

Kolejny problem, z którym musiała się zmierzyć Grupa Operacyjna, stanowiła kwestia wody zgromadzonej w zbiorniku pod reaktorem. Sowieccy specjaliści formułowali obawy, że podłoże reaktora nie wytrzyma ciężaru zrzucanego z powietrza piasku i boru. $\mathrm{W}$ takiej sytuacji wszystko - łącznie $\mathrm{z}$ pozostałym paliwem jądrowym - przedostałoby się do zbiornika, wywołując potężną eksplozję, która mogłaby doprowadzić do wyparowania paliwa z pozostałych reaktorów i w konsekwencji do katastrofy o znacznie większej niż dotąd skali. Istniała też groźba, że rozgrzane paliwo przebije się $\mathrm{w}$ dalszej kolejności przez betonowy fundament reaktora i przedostanie się do wód gruntowych, co oznaczałoby zatrucie okolicznych rzek, przede wszystkim Dniepru ${ }^{47}$. Ostatecznie woda $\mathrm{z}$ basenu została usunięta dzięki wysiłkom straży pożarnej oraz ręcznemu odkręceniu zaworów, czego dokonało trzech ochotników. Była to bardzo ryzykowna misja ze względu na konieczność przejścia przez mocno napromieniowaną wodę. Jednocześnie członkowie Grupy Operacyjnej nakazali rozpoczęcie prac, których celem było wpompowanie pod reaktor azotu. Miał on schłodzić fundament reaktora od spodu i nie dopuścić w ten sposób do jego przetopienia przez napierające resztki reaktora. Ściągnięci do Czarnobyla górnicy ręcznie wykopali 150-metrowy tunel, którym chłodziwo miało być dostarczone w okolice zniszczonego reaktora. Ostatecznie rdzeń reaktora sam wychłodził się na tyle, że nie było to konieczne, a tunel został wypełniony odpornym na wysokie temperatury betonem. Omówione wyżej kwestie techniczne stanowią dobrą ilustrację działania Grupy i jej rangi. To oczywiste, że jej członkowie-politycy nie sami znajdowali rozwiązania najistotniejszych problemów. Te suflowali specjaliści skupieni m.in. w Komisji Rządowej. To jednak członkowie Grupy podejmowali ostateczne decyzje, opierając się na przedstawionych im propozycjach, to w ich rękach skupiona była największa władza w kwestii zaradzenia problemom powstałym w wyniku awarii ${ }^{48}$.

Jednocześnie Grupa rozważała prośbę Hansa Blixa, szefa MAEA, który zabiegał o możliwość przyjazdu do ZSRS, aby na miejscu przyjrzeć się sytuacji. Ideę taką popierał m.in. Eduard Szewardnadze, szef Ministerstwa Spraw Zagranicznych, który w piśmie do KC przekonywał, że Blix ma „obiektywne” podejście (co należy rozumieć, że nie był nazbyt krytyczny wobec ZSRS) i trzeba go zaprosić do Moskwy. Argumentowal, że posunięcie to ułatwi też oddalenie wniosków innych krajów o przysłanie swoich specjalistów, na co sowieccy przywódcy nie bardzo mieli

${ }^{46}$ N. Daniloff, op. cit., s. 127-128.

47 A. Leatherbarrow, op. cit., s. 164-165.

48 N. Baranowska, op. cit., s. 227-228; A. Leatherbarrow, op. cit., s. 166-172; Protokoł № 4..., s. 261; Protokoł № 5..., s. 266; Protokoł № 11 zasiedanija Opieratiwnoj gruppy Politbiuro CK KPSS po woprosam, swiazannym s likwidacyjej posledstwij awarii na Czernobylskoj AES, 11 V 1986, w: A. Jaroszynska, Czernobyl. Sowierszenno Siekrietno..., s. 291. 
ochotę. Ostatecznie zdecydowano, że będzie to dobra okazja do ocieplenia wizerunku i pokazania światu, że włodarze ZSRS panują nad sytuacją. Blix miał zatem odegrać ważną rolę w przygotowywanym przez Moskwę propagandowym przedstawieniu. Ściśle opracowano program wizyty Blixa, zaakceptowany przez Grupę Operacyjną. Było jasne, że zobaczy on tylko to, co zechcą mu pokazać sowieccy włodarze ${ }^{49}$. Blix co prawda zdołał wyjednać zgodę na wyjazd w rejon katastrofy, ale pozwolono mu tylko na krótką wizytę i to w kabinie helikoptera. Szef MAEA był usatysfakcjonowany tym, co zobaczył. 9 maja wystąpił na konferencji prasowej, w czasie której uspokajał opinię publiczną w kwestii następstw katastrofy. On i jego współpracownicy opowiadali o normalnym życiu toczącym się na skażonych terenach oraz o stosunkowo niewielkim promieniowaniu. TASS opublikowała także komunikat mówiący o bardzo dobrej współpracy ZSRS i MAEA ${ }^{50}$. Kreml osiągnął więc swój cel - posługując się autorytetem Blixa i reprezentowanej przez niego instytucji, mógł wysłać w świat komunikat, że sytuacja jest w pełni kontrolowana. Blix nie mógł zachować się inaczej, reprezentował bowiem agencję wspierającą rozwój energetyki atomowej, a uspokajające komunikaty o katastrofie pomagały chronić ten sektor przed większymi perturbacjami ${ }^{51}$. Jeszcze jedną kwestią mogącą wpływać na stronniczość Blixa - na co zwróciła uwagę Natalia Baranowska - był duży wkład finansowy ZSRS w utrzymywaniu MAEA ${ }^{52}$.

Nie można jednak podawać w wątpliwość pewnych sukcesów szefa MAEA. Strona sowiecka przystała na prośbę dostarczania informacji o poziomie skażenia z siedmiu stacji pomiarowych, w tym jednej położonej niecałe $70 \mathrm{~km}$ od Czarnobyla. Ponadto ustalono, że MAEA będzie forum dyskusji i analizy wniosków płynących z katastrofy. ZSRS zobowiązał się do przygotowania i zaprezentowania państwom członkowskim MAEA szczegółowego raportu analizującego przyczyny, przebieg i konsekwencje awarii ${ }^{53}$.

49 Protokoł № 4..., s. 262; Protokoł № 6 zasiedanija Opieratiwnoj gruppy Politbiuro CK KPSS po woprosam, swiazannym s likwidacyjej posledstwij awarii na Czernobylskoj AES, 5 V 1986, w: A. Jaroszynska, Czernobyl. Sowierszenno Siekrietno..., s. 269; Protokoł № 8..., s. 278; [Informacja dla KC KZPR], 3 V 1986, RGANI, f. 89, op. 53, d. 3 (kopia ze strony: https://nsarchive2. gwu.edurusPerestroikaChernobyl.html [dostęp: 18.02.2019]).

50 S. Plokhy, op. cit., s. 243; Report on visit to the Soviet Union from 5 to 9 May 1986, [b.d.], Archiwum MAEA we Wiedniu, GOVINF 496, s. nlb.; The Chernobyl Nuclear Power Accident (a summary description by IAEA representatives), 9 V 1986, ibidem, s. nlb.; Communique on Blix visit to the USSR, 9 V 1986, ibidem, s. nlb.

${ }^{51}$ K. Brown, Czarnobyl. Instrukcje przetrwania, tłum. T. Gałązka, Wołowiec 2019, s. 188.

${ }^{52}$ N. Baranowska, op. cit., s. 61.

53 Director General's Statement to Meeting of the Board of Governors, 21 V 1986, Archiwum MAEA, sygn. 270-N.7.22.1, s. nlb.; Report on visit to the Soviet Union from 5 to 9 May 1986, [b.d.], ibidem, GOVINF 496, s. nlb.; Protokoł № 7 zasiedanija Opieratiwnoj gruppy Politbiuro CK KPSS po woprosam, swiazannym s likwidacyjej posledstwij awarii na Czernobylskoj AES, 6 V 1986, w: A. Jaroszynska, Czernobyl. Sowierszenno Siekrietno..., s. 273; Protokoł № 9 zasiedanija Opieratiwnoj gruppy Politbiuro CK KPSS po woprosam, swiazannym s likwidacyjej posledstwij awarii na Czernobylskoj AES, 8 V 1986, w: A. Jaroszynska, Czernobyl. Sowierszenno Siekrietno..., s. 281. 
Istotnym problemem, przed którym stanęły władze sowieckie, okazała się produkcja żywności. Ukraińska SRS, w tym regiony dotknięte katastrofą były ważnym producentem zboża, mięsa i innych produktów spożywczych. Należało zdecydować, co robić z uprawami i hodowlą prowadzonymi na terenach objętych skażeniem radioaktywnym. Ich zniszczenie oznaczałoby olbrzymie straty, co byłoby tym bardziej bolesne, jeśli wziąć pod uwagę niedobory tych towarów na rynku ZSRS. Na posiedzeniu 5 maja Grupa Operacyjna poleciła dokonać oceny skażenia produktów rolnych ${ }^{54}$. Odpowiedzią na to był najprawdopodobniej raport dla KC KPZS, przygotowany w Państwowym Komitecie Przemysłu Rolnego (Gosagroprom), a datowany na 8 maja. Jego autor przyznawał, że w kilku rejonach Białoruskiej i Ukraińskiej SRS mleko nie nadaje się do spożycia. Niemniej stwierdzał, że po przerobieniu na ser czy masło można je bezpiecznie jeść. Równie dobre rezultaty - jak pisał - przynosiło sproszkowanie mleka, które po miesiącu nadawało się do spożycia. W Gosagropromie znaleziono także sposób na wykorzystanie zwierząt rzeźnych i uniknięcie kolejnego „marnotrawstwa”. Jak raportowano, po umyciu mięsa i usunięciu węzłów chłonnych nadawało się ono do wysłania na rynek ${ }^{55}$. Żywność $\mathrm{z}$ terenów skażonych trafiła więc do sklepów w całym kraju, z pominięciem jednak stolicy. Na mocy decyzji Grupy Operacyjnej wstrzymano dostawy do samej Moskwy $^{56}$. Nawet laikowi zastosowanie takich środków, jak przeróbka skażonego mleka czy umycie mięsa może wydawać się niewystarczające. Czy tego typu zabiegi sprawiły, że w jedzeniu nie było już żadnych niebezpiecznych radionuklidów? Wątpliwości nie pozostawia chyba decyzja członków BP o wstrzymaniu dostaw do stolicy. Gdyby wspomniane produkty były całkiem bezpieczne, takiego zakazu przecież nie wydawano by. Po raz kolejny obywatele ZSRS zostali podzieleni na równych i równiejszych, a mleko i mięso udało się uchronić przed „zmarnowaniem”.

$\mathrm{Na}$ koniec warto jeszcze dodać, że w pierwszych dniach i tygodniach po katastrofie w sowieckich kręgach władzy myślano już o działaniach długoplanowych. Jedną z podstawowych kwestii było zabezpieczenie samych ruin reaktora, które w dalszym ciągu stanowiły źródło emisji promieniowania. Temat osłony dla reaktora pojawił się już na posiedzeniu Grupy Operacyjnej 10 maja, zebrani zgodnie twierdzili, że istnieje potrzeba jak najszybszego wdrożenia odpowiednich rozwiązań. Nie padło wówczas jeszcze słowo „sarkofag”, o nim mowa była kilka dni później (13 maja $)^{57}$. Myślano również o wnioskach, które należy wyciągnąć z zaistniałej

54 Protokoł № 6..., s. 270.

55 Dokument nr 93, Informacija hołowy Derżagropromu SRSR W. Murachowśkoho dla CK KPRS pro stan i zachody szczo do likwidaciji naslidkiw awariji na CzAES u silśkomu hospodarstwi, 8 V 1986, w: Czornobylśka trahedija..., s. 113.

56 Protokoł № 10 zasiedanija Opieratiwnoj gruppy Politbiuro CK KPSS po woprosam, swiazannym s likwidacyjej posledstwij awarii na Czernobylskoj AES, 10 V 1986, w: A. Jaroszynska, Czernobyl. Sowierszenno Siekrietno..., s. 286.

57 Ibidem, s. 287; Protokoł № 13 zasiedanija Opieratiwnoj gruppy Politbiuro CK KPSS po woprosam, swiazannym s likwidacyjej posledstwij awarii na Czernobylskoj AES, 13 V 1986, w: A. Jaroszynska, Czernobyl. Sowierszenno Siekrietno..., s. 301. 
sytuacji. Przede wszystkim powstał zespół, którego zadaniem było przygotowanie raportu o przyczynach katastrofy. Przedmiot oceny miało stanowić także bezpieczeństwo reaktorów typu RBMK-1000. Biorąc pod uwagę, że na terenie ZSRS funkcjonowało więcej tych urządzeń, kwestia ta wiązała się $\mathrm{z}$ bezpieczeństwem i zapobiegnięciem podobnych awarii w przyszłości. Członkowie Politbiura zlecili też zbadanie wpływu awarii na środowisko naturalne - głównym celem miała być ocena możliwości przywrócenia normalnego funkcjonowania obszarów skażonych. Najwidoczniej łudzono się jeszcze wówczas, że ewakuowani będą mogli kiedyś wrócić do domów i przystąpić do uprawy ziemi i hodowli zwierzą ${ }^{58}$.

Sam Gorbaczow zabrał publicznie głos w sprawie Czarnobyla dopiero 14 maja. $\mathrm{W}$ wystąpieniu telewizyjnym mówił m.in. o ofiarach i hospitalizowanych oraz przekazał wyrazy współczucia wszystkim poszkodowanym. Złożył podziękowania lekarzom i specjalistom z zagranicy za okazaną pomoc. Apelował także o zwołanie międzynarodowej konferencji pod egidą MAEA i zwiększenie roli tej organizacji ${ }^{59}$. Oczywiście pierwsze pytanie, które się narzuca, to dlaczego sekretarz generalny tak długo zwlekał ze swoim wystąpieniem? Wydaje się, że najistotniejsze były dwa czynniki, które jednocześnie determinowały wcześniejszą politykę informacyjną. Po pierwsze, sowieckie kierownictwo zdecydowało się na dostarczanie społeczeństwu jedynie skąpych i wygładzonych informacji w obawie przed niekontrolowanym wybuchem paniki. Ta obawa mogła też być przyczyną zwłoki w sprawie szerszego wystąpienia telewizyjnego. Po drugie, w pierwszych dniach nie posiadano pełnej wiedzy o skali i charakterze wydarzenia ${ }^{60}$. Gorbaczow sam później przyznawał, że zdecydował się na publiczne wystąpienie dopiero wówczas, gdy dysponował pełniejszą wiedzą o katastrofie i jej następstwach ${ }^{61}$. Inna kwestią jest, dlaczego Gorbaczow - wraz z Ryżkowem i Ligaczowem - nie udał się na miejsce tragedii, do Czarnobyla? Można wręcz odnieść wrażenie, że całą sprawę zepchnął właśnie na premiera Ryżkowa ${ }^{62}$. Może było to tylko zwyczajne nakładanie obowiązków na jednego ze swoich najbardziej zaufanych, a może kryła się za tym bardziej przemyślana strategia - niewiązanie własnej osoby $z$ tak niefortunnym wydarzeniem, jak katastrofa czarnobylska. Mogło mieć to znaczenie w kontekście nowego otwarcia proponowanego przez Gorbaczowa - Czarnobyl na pewno nie służyłby wizerunkowi nowego przywódcy. Jeśli było tak w istocie, to przed 14 maja Gorbaczow

58 Protokoł № 9..., s. 283; Protokoł № 14 zasiedanija Opieratiwnoj gruppy Politbiuro CK KPSS po woprosam, swiazannym s likwidacyjej posledstwij awarii na Czernobylskoj AES, 14 V 1986, w: A. Jaroszynska, Czernobyl. Sowierszenno Siekrietno..., s. 304.

59 A. Stępień-Kuczyńska, Michaił Gorbaczow a idea i praktyka pieriestrojki, Łódź 2016. Całe wystąpienie Gorbaczowa zostało opublikowane w prasie następnego dnia, zob. np. Wystuplenije M.S. Gorbaczowa po sowietskomu telewidieniju, „Izwiestija” (15 V 1986).

${ }^{60}$ M. Gorbaczow, Sam ze wspomnieniami, tłum. O. Morańska, Warszawa 2014, s. 282.

${ }^{61}$ Wywiad z Michaiłem Gorbaczowem, http://news.bbc.co.uk/2/hi/europe/4918940.stm (dostęp: 12.07.2018).

${ }^{62}$ N. Daniloff, op. cit., s. 126. 
przewartościował swoje myślenie i zdecydował się na telewizyjne orędzie w sprawie katastrofy. Uznał, że wyczerpująca informacja na jej temat może właśnie przysłużyć się jego wizerunkowi, pomóc mu wykreować się w oczach społeczeństwa jak i opinii publicznej na Zachodzie na przywódcę otwartego, wiarygodnego i gotowego do przyznania się do błędów. To jak najbardziej wpisywało się w ogłoszoną przez niego głasnost.

\section{Podsumowanie}

W ogólnym przekonaniu brak właściwej reakcji władz sowieckich, szczególnie w pierwszych godzinach i dniach po wypadku, przypisywany jest polityce tajności i niechęci do przedstawienia jakiejkolwiek informacji opinii publicznej w kraju i na świecie. Jak się okazuje, to tylko część prawdy. Główny powód braku szybkich i zdecydowanych działań stanowiło początkowe niedocenienie skali zagrożenia, co było wynikiem dezinformacji ze strony kierownictwa elektrowni ${ }^{63}$. Niemniej, kiedy władze sowieckie zorientowały się, że sytuacja jest dużo poważniejsza, niż im wcześniej raportowano, powzięły zdecydowane kroki, by zapobiec dalszej eskalacji niebezpieczeństwa. Jako egzemplifikacja może posłużyć ewakuacja Prypeci. Kierownictwo partii jej nie zakwestionowało, mimo iż wiedziano, że będzie się wiązała z dużymi kosztami społecznymi i politycznymi. Brak natychmiastowej decyzji w tej sprawie np. 26 kwietnia rano wynikał przede wszystkim z początkowo błędnej oceny sytuacji. Nikt jednak w dalszym ciągu nie myślał o możliwych skutkach zdrowotnych u ludzi mieszkających w miejscach bardziej oddalonych od elektrowni. Na terenach skażonych można było przeprowadzić choćby akcję podawania jodku potasu dzieciom. Ograniczyłoby to stopień wchłaniania przez ich tarczyce radioaktywnego J-131, który znalazł się w powietrzu po wybuchu (podany doustnie jod blokował tarczycę, tak iż nie przyjmowała już szkodliwego jodu z powietrza $)^{64}$. Taką akcję przeprowadzono w Polsce - objęła ona $18,5 \mathrm{mln}$ ludzi, w tym 10,5 mln dzieci. Są badania potwierdzające, że wpłynęło to na zmniejszenie odsetka dzieci cierpiących w późniejszych latach na różnorakie choroby tarczycy ${ }^{65}$. W ZSRS jednak nie myślano wówczas o dalekosiężnych

${ }^{63}$ E. Geist, op. cit., s. 106.

64 Temat profilaktyki jodowej podjęty został dopiero 7 maja, kiedy Grupa Operacyjna zleciła Ministerstwu Przemysłu Chemicznego wyprodukowanie 130 ton płynu dla jego - jak pisano - ewentualnego zastosowania $\mathrm{w}$ celu ograniczenia szkodliwego wpływu promieniowania. Jak więc widać, ZSRS nie dysponował nawet zapasami jodku potasu, musiał go dopiero wyprodukować. Zresztą i tak nie było to równoznaczne z decyzją o jego rozdystrybuowaniu. Jedynie w samej Prypeci 27 kwietnia oraz w Briańsku (z inicjatywy obrony cywilnej) akcja taka została przeprowadzona, E. Geist, op. cit., s. 123; Protokoł № 8..., s. 278.

65 Czarnobyl dał nam nauczkę (wywiad z prof. Idą Kinalską), https://poranny.pl/czarnobyl-dal-nam-nauczke/ar/5042354 (dostęp: 22.08.2019); https://www.salon24.pl/u/zdrowie/861784,katastrofaw-czarnobylu-promieniotworczy-jod-i-plyn-lugola (dostęp: 22.08.2019). 
skutkach katastrofy, wszystkie działania i środki zostały skupione na doraźnej walce z emisją promieniotwórczości i ewakuowaniu ludności mieszkającej blisko elektrowni. Ograniczeniu negatywnych skutków zdrowotnych katastrofy mogła też służyć pełniejsza informacja o skali i rodzaju zagrożenia, uzupełniona o odpowiednie zalecenia służące ograniczeniu negatywnych konsekwencji zdrowotnych. Silniejsza jednak okazała się obawa przed niekontrolowanym wybuchem paniki, stąd też bardzo skromne i nieadekwatne do skali wydarzenia informacje pojawiąjące się $\mathrm{w}$ rodzimych mediach.

Nie można też wykluczyć, że wpływ na brak pełnych danych o katastrofie miało nuklearne lobby istniejące w ZSRS. Dotychczasowe perturbacje (co prawda o niewielkiej skali) były skrzętnie ukrywane. Elektrownie atomowe miały być filarem sowieckiego sektora energetycznego, dlatego powinien uchodzić za całkowicie bezpieczny i bezawaryjny ${ }^{66}$. Faktycznie taka wiara istniała m.in. w kręgach rządowych. Gorbaczow wspominał, jak szef Instytutu im. I. Kurczatowa Anatolij Aleksandrow przekonywał go przed katastrofą, że reaktory RBMK-1000 są tak bezpieczne, że można by je zainstalować na pl. Czerwonym w Moskwie ${ }^{67}$. Ograniczanie informacji na temat awarii mogło więc służyć nie tylko zapobiegnięciu wybuchu paniki, ale też leżało w interesie twórców i propagatorów energetyki jądrowej.

Trudno nie zauważyć, że w obliczu katastrofy czarnobylskiej władze sowieckie zadziałały w dość charakterystyczny dla siebie sposób: rzuciły do walki z „wrogiem” wszelkie dostępne siły i środki, nie przykładając należytej wagi do poniesionych strat ludzkich. Było to jeszcze bardziej widoczne w kolejnych tygodniach i miesiącach w czasie akcji dekontaminacyjnej i usuwania fragmentów uszkodzonego reaktora, do czego wysłani zostali tzw. likwidatorzy oraz bioroboty. Reaktor udało się więc ugasić i przykryć go betonowym sarkofagiem. Walka została wygrana, ale do dzisiaj uwidaczniają się negatywne skutki zdrowotne, z których części na pewno można było uniknąćc8.

66 S. Plokhy, op. cit., s. 174.

${ }^{67}$ Ibidem, s. 121.

${ }^{68}$ Konsekwencje zdrowotne i środowiskowe katastrofy na terenach najbardziej skażonych stanowiły przedmiot badań kilku organizacji międzynarodowych. Według raportów opracowanych przez UNSCEAR (Komitet Naukowy ONZ ds. Skutków Promieniowania Atomowego) bezpośrednich ofiar było $31, \mathrm{z}$ czego 28 zmarło krótko po awarii wskutek ostrej choroby popromiennej, a $3 \mathrm{z}$ innych przyczyn, W 20-tą rocznicę awarii czarnobylskiej elektrowni jądrowej, oprac. W. Trojanowski, L. Dobrzyński, E. Droste, http://ncbj.edu.pl/zasoby/awarie/20_rocznica_czarnobyla. pdf (dostęp: 12.11.2019), s. 14-15. Naukowcy badający poszkodowaną populację nie stwierdzili bezsprzecznego związku między ekspozycją na promieniowanie a wzrostem zachorowań na raka, białaczkę czy inne choroby. Z jednym jednak wyjątkiem, nie ulega bowiem wątpliwości, że uwolnione wówczas promieniowanie stało się przyczyną wzrostu liczby zachorowań na raka tarczycy, w szczególności u dzieci. Według danych z 2015 r. w latach 1991-2015 zdiagnozowano 16 tys. przypadków raka tarczycy u osób, które w momencie awarii miały mniej niż 18 lat, Thyroid Cancer and Nuclear Accidents. Long-term Aftereffects of Chernobyl and Fukushima, ed. S. Yamashita, G. Thomas, London 2017, s. 17-18. 


\section{The Authorities of the Soviet Union towards the Chernobyl Disaster}

\section{Abstract}

In my article, I will investigate the reaction of the Soviet authority to the Nuclear Power Plant disaster in Chernobyl on 26 April 1968. To date, no one has shed sufficient light on this problem, and there are also no published works that refer to accessible Soviet documents on this topic. I managed to gain access to some declassified documents gathered in Fond 89, located in the Russian State Archive of Contemporary History in (RGANI), as well as access to the protocols of Operation Group of the Central Committee of the Communist Party of the Soviet Union. This group, headed by the then Prime Minister Nikolai Ryzhkov, seems to have played a significant role in the decision making process following the accident in Chernobyl. The documents mentioned above and the existing literature on the subject will be the basis for my text.

In my manuscript, decisions made by authorities in the crucial period directly following the accident concerning the reactor fire, decontamination of polluted area, as well as the protection of the people's health and life will be assessed. Finally, information policy in the USSR and abroad will be discussed. According to the circulating information, the crucial mistakes that were made, particularly in the first hours and days, were as a result of a policy of secrecy and a reluctance to provide reliable information to the domestic and international public. It appears the main reason for the lack of quick and decisive actions could be attributed to an underestimation of the scale of the disaster by relevant authorities. This underestimation was mainly influenced by false reports delivered by the management of the power plant. Nonetheless, when the Soviet authorities realised the aftermath of the accident, it took concrete steps to prevent further escalation of the situation.

\section{Отношение властей Советского Союза к чернобыльской катастрофе}

\section{Аннотация}

Основной целью статьи является изложение реакции советских властей на катастрофу в Чернобыле (26 апреля 1986 г.). До сих пор этот вопрос не был достаточно освещен. Не хватает работ, которые полностью использовали бы доступные советские документы на эту тему. Мне удалось обнаружить рассекреченные документы, находящиеся в фонде 89 РГАНИ, а также протоколы Операционной группы Политбюро ЦК КПСС, председателем которой был премьер-министр Николай Рыжков (Группа играла тогда самую важную роль в процессе принятия решений). На этих документах, а также на доступной литературе основывается моя статья.

В тексте поддаются оценке действия властей в первый, самый опасный, период после катастрофы, как касающиеся тушения пожара, ликвидации последствий аварии, так и охраны здоровья и жизни жителей, а также информационной политики, как в стране, так и за рубежом. Согласно распространенному мнению, ошибки, особенно совершенные в первые дни и часы, были результатом, прежде всего, желания замять дело, как перед собственными гражданами, так и международной общественностью. Однако кажется, что главной причиной отсутствия быстрых и решительных действий была недооценка масштаба угрозы, что, в свою очередь, было результатом ошибочных докладов, отправляемых в Москву руководством АЭС. Когда люди осознали серьезность положения, были предприняты соответствующие меры, предотвратившие дальнейшее ухудшение ситуации. 


\section{Bibliografia}

Baranowska N., Ispytanije Czernobylem, Kijów 2016.

Brown K., Czarnobyl. Instrukcje przetrwania, tłum. T. Gałązka, Wołowiec 2019.

Czornobylśka trahedija. Dokumenty i materiały, red. N. Baranowska, Kijów 1996.

Daniloff N., Chernobyl and Its Political Fallout: A Reassessment, „Demokratizatsiya The Journal of Post-Soviet Democratization" 12 (2004), no. 12.

Geist E., Political Fallout: The Failure of Emergency Management at Chernobyl', „Slavic Review” 74 (2015), no. 1 .

Higginbotham A., Midnight in Chernobyl. The Untold Story of the World's Greatest Nuclear Disaster, London 2019.

Higginbotham A., O północy w Czarnobylu, tłum. R. Filipowski, Kraków 2019.

Jaroszynska A., Chernobyl. The Forbidden Truth, Lincoln 1995

Jaroszynska A., Czernobyl. Bolszaja łoż, Moskwa 2011.

Jaroszynska A., Sowierszenno Siekrietno, Moskwa 1992.

Leatherbarrow A., Chernobyl. 01:23:40, [b.m.w.] 2016.

Marples D.R., The Social Impact of the Chernobyl Disaster, Houndmills-Basingstoke-London 1988.

Medvedev G., The Truth about Chernobyl, Nowy York 1991.

Pichoja R.G., Sowietskij Sojuz. Istorija własti 1945-1991, Nowosybirsk 2000.

Plokhy S., Chernobyl. The History of a Nuclear Catastrophe, New York 2018.

Plokhy S., Czarnobyl. Historia nuklearnej katastrofy, tłum. M. Fedyszak, Kraków 2019.

Read P.P., Czarnobyl. Zapis faktów, tłum. J. Kubowski, Warszawa 1996.

Revelations from the Russian Archives. Documents in English Translation, ed. D.P. Koenker, R.D. Bachman, Washington 1997.

Stępień-Kuczyńska A., Michaił Gorbaczow a idea i praktyka pieriestrojki, Łódź 2016.

Thyroid Cancer and Nuclear Accidents. Long-term Aftereffects of Chernobyl and Fukushima, ed. S. Yamashita, G. Thomas, London 2017.

Kamil Dworaczek, dr, historyk; pracownik naukowy w Oddziale Instytutu Pamięci Narodowej we Wrocławiu. Zainteresowania naukowe: opozycja w PRL (głównie NSZZ „Solidarność” i opozycja studencka), katastrofa czarnobylska i jej konsekwencje (kamil.dworaczek@ipn.gov.pl).

Kamil Dworaczek, PhD, historian, employee of the Wrocław Branch of the Institute of National Remembrance. Scholarly interests: opposition in People's Poland (mainly the Trade Union Solidarność and the student opposition), the Chernobyl disaster and its consequences (kamil.dworaczek@ipn.gov.pl). 